Khazanah: Jurnal Studi Islam dan Humaniora

ISSN: 0215-837X (p); 2460-7606 (e), Vol. 17 (1), 2019, pp. 83-106

DOI: 10.18592/khazanah.v17il.2884

Submit : 24/05/2019 Review : 24/06/2019 Publish : 30/07/2019

\title{
HERMENEUTICS OF NATIONALITY FIQH: STUDY OF BAHTSUL MASAIL OF LIRBOYO ALUMNI ASSOCIATION
}

\author{
Iis Kholilah \\ Universitas Islam Negeri Walisongo, Semarang \\ abyadujasmine@gmail.com
}

\begin{abstract}
This article analyses the text of babtsul masail from the alumni of Lirboyo Islamic traditional boarding school focusing on the motive bebind its publication, the basic concept of nationalism proposed by the text, the dominance of legal reasoning used in the text and its potential toward the readers. By employing critical hermeneutic approach, there were three stages of analysis, i.e. socio-historical analysis, text analysis and interpretation of the text. According to the analysis this research concludes that the recent phenomenon of the rising of anti-nationalism Islamic movement led by Hizbut-Tabrir and certain radical hard-line organization since 2000s has been the main motive of the publication of the text. This text also proposes the meaning of nationalism as the intention to love the nation and country and its consequences as a Moslem in Indonesian context. Moreover Qauliyah has had been used as the main legal reasoning to formulate certain concepts and this text might be less compatible for the prospective readers outside the Santri's community. Because many arguments from Arabic resources scattered throughout the text in which still need depth explanation for the beginners.
\end{abstract}

Keywords: Babtsul Masail; Critical Hermeneutic; Nationality Fiqh; Nabdlatul Ulama

\section{Introduction}

Since 1998 political reform, identity politics has colored the political stage, both practical and ideological in Indonesia. One of the expressions of identity politics is the rise of an ideological Islam-political spirit that does not only have positive potential for the development of the Indonesian nation, but can be potentially disintegrative. One group that might represent this negative trend is Hizbut-Tahrir Indonesia (HTI). Until now, even after being declared dissolved by the government of the exponents of HTI, it still launched its ideological propaganda. ${ }^{1}$ In this case,

${ }^{1}$ Biro Humas Kerjasama Hukum dan, "Kewenangan Legal Administratif Kemenkumham Sebagai Tindak Lanjut Perppu No. 2 Tahun 2017," Kementerian Hukum dan Hak Asasi Manusia Republik Indonesia, October 5, 2019, https://kemenkumham.go.id/publikasi/siaran-pers/kewenangan-legal-administratifkemenkumham-sebagai-tindak-lanjut-perppu-nomor-2-tahun-2017. 
the single idea brought by HTI was to change the state system to become the al-Khilafah al-Islamiyyah. It is always voiced that Muslims must use the laws of Allah SWT, those who do not rule with the law of Allah SWT -use of the laws of human products-, then they have not become a devout Muslim or kaffah. ${ }^{2}$ Everything that comes from humans, including the idea of nationalism is considered incompatible with Islam because there are no arguments which is equated with al asabiyyah (tribal fanaticism). ${ }^{3}$ The ideology brought by HTI is certainly has an impact on the nation disintegration, because when the love of the mortherland fades away, there will be no desire to defend it when there are those who want to destroy it. If this is allowed, the opportunity for those who intend to harm Indonesia will be increasingly wide open.

Most groups exposed to the issue of nationalism has no argument and are precisely the upper middle class or from educated people. Perhaps the lack of gradual learning about Islamic studies and the complexity of indepth references to fiqh make them more likely to access material that is practical. Therefore, in an effort to answer the argument from the exponent of Hizbut-Tahrir that nationalism has no arguments, it is necessary to conduct a work that can provide a comprehensive foundation of fiqh which is compatible with nationalism. In this case, the work of the Santri Lirboyo Alumni Association (Himasal) entitled "Fikih Kebangsaan: Merajut Kebersamaan di Tengah Kebhinnekaan" seems to have the potential to answer these public needs because it is published in February 2018, it contains the legal principles of Islamic nationalism. In addition, the work becomes more interesting because it was formally prepared by

${ }^{2}$ Makmun Rasyid, Hiæbut Tahrir Indonesia: gagal paham khilafah (Tangerang: Pustaka Compass, 2016).

${ }^{3}$ KH. Ahmad Ngisomudin, "Gerakan Politik HTI Berbalut Dakwah Menuju Khilafah Islamiyyah,” retrieved on October 1st, 2019., https://www.suaraislam.co/wpcontent/uploads/2018/HTI-PTUN.pdf., 14. This is an academic text presented on March 15, 2018 as evidence of trial before the PTUN Judges in a TUN lawsuit filed by ex-HTI regarding the Minister of Law and Human Rights Decree Number: AHU30.AH.01.08 in 2017 concerning Revocation Decree of the Minister of Law and Human Rights Number: AHU-0028.60.10. 2014 concerning Ratification of the Establishment of HTI Legal Entities. 
the santri organization which is at the heart of the Nahdlatul Ulama, namely the santri alumni of the Lirboyo Islamic boarding school, Kediri, East Java.

Nahdlatul Ulama (NU) in this case indeed appears as an Islamic organization in Indonesia which has lately been keen to campaign for the need for Muslims to love the homeland and be loyal to the country and nation. Some of the previous works have raised the theme of Islam and Nahdlatul Ulama nationalism. Abdul Chaliq Murod for example examines nationalism in an Islamic perspective.

NU's nationalist attitude is an example of a review, especially NU's nationalism in the form of jihad during colonialism such as ijtihad, the land of the Dutch East Indies as an Islamic territory, the call for jihad resolution and others. ${ }^{4}$ Similar studies were carried out by Muhammad Alwi Lutfi, Karim Suryadi, and Endang Sumantri regarding NU's idea in fostering and defending Indonesian nationalism, efforts made by NU in realizing the Republic of Indonesia as baldatun tayyibatun wa rabbun gafur, NU's view of the transnational Islamic movement, as well as the thoughts and roles of $\mathrm{NU}$ in realizing good citizens and efforts to improve the nation's morals. ${ }^{5}$

A relatively recent study was conducted by Zudi Setiawan. He formulated the NU paradigm of the relationship between Islam and the state which was influenced by several factors, namely NU's religious understanding (ablu al-sunnah wa al-jama'ah), the basis of NU's political thinking (which refers to Sunni political thinking including divinity, deliberation, justice, freedom, and equality), and the plurality of the Indonesian people. In addition, Setiawan also formulated NU's national

\footnotetext{
${ }^{4}$ Abdul Choliq Murod, "Nasionalisme dalam Pespektif Islam", Citra Lekha 15, no. 2 (September 2, 2011): 45-58. Retrieved on June $5^{\text {th }} 2017$, http://www.ejournal.undip.ac.id/index.php/cilekha/article/view/5039 /4573 .

${ }^{5}$ Mohamad Alwi Lutfi, Karim Suryadi, and Endang Somantri, "Role Of Nabdlatul Ulama in Fostering Indonesian Nationalism in Effort to Realize Baldatun Thayyibatun Wa Robbun Ghofur," Jurnal Civicus 18, no. 2 (December 2, 2014): 1-17, retrieved on June $5^{\text {th }} 2017$, http://ejournal.upi.edu/index.php/civicus/article/view/2042. Muqarramah Sulaiman Kurdi, "Madrasah Ibtidaiyah dalam Pandangan Dunia: Isu-Isu Kontemporer dan Tren dalam Pendidikan," Al Ibtida: Jurnal Pendidikan Guru MI 5, no. 2 (October 31, 2018): 231-48, https://doi.org/10.24235/al.ibtida.snj.v5i2.3194.
} 
ideology, namely: (1) refers to Walisongo teachings (bubbu al-waton min aliman), (2) the life of nation and state is a fit and human need, (3) the needs of nation and state built on the principles of divinity, sovereignty, justice, equality, and deliberation, (4) refers to the richness of the history and culture of the archipelago. The needs of the nation and state are built on the principles of divinity, sovereignty, justice, equality, and deliberation, (5) refersto the richness of the history and culture of the archipelago. ${ }^{6}$ Some of these works can be said to be relatively touching on NU's basic views in practicing nationalism. However, it seems that some of these works have not examined the basic fiqh and reasoning models regarding the concept of nationalism by looking at the text and context comprehensively.

This paper examines 4 scopes, namely the context of the birth of text - in this case the national jurisprudence of Himasal's works, the substance / meaning of the text both implied and implicit in building the concept of nationalism according to Himasal, the type of legal reasoning and the readability potential of this text general prospective readers. Himasal's work is important to study because the fiqh argument about nationalism compiled by Himasal is quite comprehensive, so it is expected to be a counter to the ideology of HTI. In addition, this work is interesting because it was produced from among santri (the babtsul masail results of the alumni of the santri Islamic boarding school of Lirboyo which have been widely recognized in their ability to study fiqh and the understanding of classical books). However, until now, as far as the search for the author, no one has reviewed Himasal's work.

\section{Method}

The researcher in this case uses a critical hermeneutic approach to know the legal reasoning method used by Himasal in formulating the interesting book. Critical hermeneutics is a methodology to understand and interprete the meaning of symbolic expressions, including text, by emphasizing the context of the birth of the text, including also in the form

${ }^{6}$ Zudi Setiawan, Nasionalisme NU (Semarang: Aneka Ilmu, 2007). 
of power relations and domination. ${ }^{7}$ Thompson said that critical hermeneutics in understanding texts considers context-power, ideology, history- as important things that influence the text. The understanding of text and context relations is then used to understand the text more specifically. It is at this level that critical interpretation is carried out. Thus, critical hermeneutics is nothing but the theory of critical interpretation, especially the critical theory of Habermas, towards social phenomena, including the text. ${ }^{8}$

Referring to the methodological approach of critical hermeneutics, especially Thompson, the researcher will first examine the socio-cultural context of the Himasal text, especially the socio-cultural conditions of Islam in Indonesia around the production of the text. Then it only leads to the substance of the text in the form of legal formulations, especially to identify the types of legal reasoning methods. The way to identify legal reasoning is by looking at how an argument is built, refer to what (basically), and why and how the substance of a concept is built. In accordance with the critical hermeneutic approach, researcher, in addition to considering the socio-cultural context of the birth of the text, also consider the explicit and implicit meaning of the arguments put forward by Himasal using a psychological-social perspective. That way it will be able to know the type of legal reasoning method used and the express and implied messages. ${ }^{9}$

${ }^{7}$ See also Hans-Herbert Kögler, "Critical Hermeneutics", Jeff Malpas and HansHelmuth Gander, The Routledge Companion to Hermeneutics, 2015. in Lisa Given, The SAGE Encyclopedia of Qualitative Research Methods (2455 Teller Road, Thousand Oaks California 91320 United States: SAGE Publications, Inc., 2008), retrieved on April 11 th 2019 , https://doi.org/10.4135/9781412963909.

8John B Thompson, Critical Hermeneutics: A Study in the Thought of Paul Ricoeur and Jürgen Habermas - Kindle Edition by John B. Thompson. (Cambridge, New York, Melbourne: Cambridge University Press, 2003), 216-218. F. Budi Hardiman, "Kritik Ideologi, Menyingkap Pertautan Pengetahuan Dan Kepentingan Bersama Jurgen Habermas," Yogyakarta: Penerbit Kanisius, 2009.

9 John B. Thompson, Critical Hermeneutics See also Jhon Thompson, "Kritik Ideologi Global: Teori Sosial Kritis Tentang Relasi Ideologi Dan Komunikasi Massa, Terj," Haqqul Yakin. Yogyakarta: IRCiSoD, 2006., Roy J. Howard, "Pengantar Teori-Teori Pemahaman Kontemporer: Hermeneutika: Wacana Analitik, Psikososial Dan Ontologis, 
Iis Kholilah

\section{Discussion}

The discussion on the text of Himasal using the critical hermeneutic approach is divided into several subsections, namely review of (1) the socio-historical context of the birth of the text, (2) interpretation or interpretation of the meaning of nationalism in the Himasal text, (3) interpretation of the concept of consequences of Muslims in Indonesia, (4) the dominance of Qauliyah's reasoning carried out by the Babtsul team during the period of the santri alumni of the Lirboyo Islamic boarding school, and (5) the potential to be understood and used as a counter discourse by readers to transnational Islamic and hardline Islamic discourse.

\section{The Socio-Historical Context of the Text}

Himasal's work consists of 6 sections. Chapter I reviews the definition of the Unitary State of the Republic of Indonesia (NKRI) as mu'abadah wataniyyah, Chapter II titled "NKRI sebagai Harga Mati”, Chapter III concerning guarding legitimate government, Chapter IV reviews differences is a necessity, Chapter $\mathrm{V}$ reviews that provocation is not the teachings of ablu al -sunnah wa al-jama'abal-nabdiyyah, and Chapter VI describes the Himasal recommendations. Extensive discussion from the notion of the NKRI to the description that provocation is not the teachings of ablu al-sunnah wa al-jama'ah al-nabdiyyah seems to indicate that Himasal's work was occurred in response to the practice of religious models of Muslims today who began to disagree with nationalism on the other hand it shows a provocative.

When this book by Himasal contains arguments regarding the compatibility of nationalism and Islamic teachings, ethics and the obligation to respect the legitimate government - in this case the context is certainly the legitimate government of Indonesia, then clearly what is targeted is to provide rival arguments for Muslims who campaign vigorously understand that nationalism has no argument in Islam. In this

Terj," Kusmana Dan MS. Nasrullah,(Bandung: Nuansa, Cet. II 2001), 2001. and Richard E. Palmer, Hermeneutika: Teori Baru Mengenai Interpretasi (Pustaka Pelajar, 2003). 
case, Hizbut-Tahrir Indonesia (HTI) has been dissolved by the government. Obviously in various publications circulating both in print and on the network (online), the Al Islam bulletin distributed in mosques every Friday and the current official HTI website has been removed from cyberspace.

A similar response was also made by $\mathrm{NU}$ in the history of the Indonesian nation's journey since the reign of President Soekarno to Suharto. Movements from some Muslims that have the potential to cause prolonged conflict such as those carried out by Kartosuwiryo with the Darul Islam/ Indonesian Islamic Army (DI / TII) and the Indonesian Islamic State (NII) were also opposed by NU by taking political steps and spreading rival discourse. In this case, Andree Feillard stated that according to the Sunni tradition adopted by NU, NU seemed to always be in an effort to maintain order. ${ }^{10}$ Likewise when several Masyumi figures, including Natsir founded the Revolutionary Government of the Republic of Indonesia (PRRI), NU chose a different path. NU sees Natsir's steps as a loss for Muslims as a whole, because it will certainly be crushed and produce conflict. $^{11}$

The characteristics of NU's cultural and political attitudes that are responsive to discourses and movements that have the potential to lead to conflict between Muslims in Indonesia and other fellow citizens seem to be based on the opinion that a harmonious life in the state is important. Therefore, it is only natural that NU also responded expressly to the discourse echoed by HTI regarding the Khilafah Islamiyah. The discourse is relative to the discourse echoed by DI / TII and PRRI in the past. NU's attitude towards HTI can be said to be consistent in continuing NU's attitude in the face of movements that have the potential to harm Muslims themselves, as well as harming the state where Muslims live. It's just that in Himasal's book, it does not explicitly mention the name of HTI and similar movements.

10 Andree Feillard, NU Vis a Vis Negara; Pencarian Isi, Bentuk Dan Makna (Yogyakarta: LKiS, 2008), 38-39.

${ }^{11}$ Feillard, 48. 
The book is also related to the arguments to legitimize the practice of life and tolerance between Muslims and non-Muslims and the arguments for prohibiting provocation, blasphemy, and verbal abuse that have the potential to produce community conflicts. It can be interpreted that this is a response to the Indonesia post-reform context, one of which is the birth of mass labeled Islamic organizations that tend to prioritize violence, blaspheme, and provocative. In this case, the Islamic Defenders Front (FPI) and a number of similar organizations were seen in several activities, especially some of their leaders who were often seen showing blasphemous behavior and berating state leaders. ${ }^{12}$ Thus it is clear that the context of the birth of the text is the phenomenon of some Muslims which have the potential to cause chaos and conflict in Indonesia.

The socio-cultural context which is also a consideration of Himasal's work is geopolitical development in the Middle East. Especially when the Arab Spring happened in 2010 until now the most recent is the emergence of chaos in Syria with the presence of the Islamic State of Iraq and Syria (ISIS). On the other hand, the presence of technology that makes it easy for people to have website pages and personal accounts on various social media, it also becomes a means to spread hoaxes that contribute to provoking, potentially bringing conflict and national disintegration. ${ }^{13}$ This context is clearly stated in chapter I of this book. It is from the real sociocultural context that occurs today in a national, international context, and involves Muslims directly.

If this is explored further, it can be interpreted that the fact of the prolonged conflict that occurred in the Middle East, such as in Iraq, Libya, Syria, and Yemen - as well as Afghanistan — has become an empirical basis for NU to worry about the harsh, extreme, and reluctant style committing violence and terror in the name of Islam. NU even has a long

12 Abba Gabrillin, "Perjalanan Kasus Rizieq, Penodaan Pancasila hingga 'Chat WhatsApp' yang Berujung Dihentikan Halaman all," KOMPAS.com, accessed October 2, 2018, https://nasional.kompas.com/read/2018/06/17/09394031/perjalanan-kasusrizieq-penodaan-pancasila-hingga-chat-whatsapp-yang.

${ }^{13}$ Tim Bahtsul Masail HIMASAL, Fikih Kebangsaan: Merajut Kebersamaan di Tengah Kebbinnekaan, (Lirboyo: Lirboyo Press dan LTN HIMASAL, 2018), 1. 
history in the scientific series with the immediate Middle East. Many NU scholars studied directly especially in Mecca and Yemen. NU even responded directly to the Wahhabi movement which sought to get rid of the religious traditions in Saudi Arabia by forming the Hijaz Committee. A strong sense of belonging to the land where Islam was born and the teachers of NU scholars seems to have made NU not willing if the same conflict also spread to Indonesia. The character of Islam that is rigid as indicated by ISIS and the Taliban, in a certain degree is not much different from HTI and FPI. Therefore, so that Indonesia does not have the fate of countries in the Middle East which also harm Muslims, the elements of violence in religion and the discourse of national disintegration must be resisted.

Based on the explanation it is clear that the book by Himasal was not born without context. There is a possibility that the political motives behind the publication of this text do exist, but the researcher look too far to conclude the existence of political motives - especially practical politics - because this publication was purely published by Himasal, not by NU structural administrator. ${ }^{14}$ There are two loci in this case, namely the international locus - especially in the Middle East - and national. Both of them have a strong religious tendency and try to establish the al-Khilafah alIslamiyyah. Only the actors are different, in the Middle East the actors are ISIS, the Taliban, Al Qaeda, while in Indonesia include HTI, FPI, and others. Of course the conflict in the Middle East in this case is inseparable from the United States (U.S.) foreign policy, but the actors in the field still show a violent and extreme attitude.

\section{Interpretation of the Meaning of Nationalism}

Furthermore, as far as the writer have searched, it is clear that the motivation of the occurance of this book is the enthusiasm for juxtaposing

${ }^{14}$ The history of NU's contact and politics, including the ruling government regime can be read further in the work of Feillard, NU Vis a Vis Negara; Pencarian Isi, Bentuk Dan Makna. Even up to now (2019) many NU cadres have obtained strategic positions in the ruling government, both as ministers and even the Vice President. 
Islam and the understanding of nationality or nationalism. The first thing can be seen from the explicit title "Fikih Kebangsaan: Merajut Kebersamaan di Tengah Kebhinnekaan”. The term jurisprudence itself implies a special discussion in the field of Jurisprudence which addresses the study of the nation. Furthermore, the subtitle " merajut kebersamaan di tengah kebhinnekaan" also shows the distinctiveness of various Indonesian contexts, even the terms used are very unique, namely "bineka" taken from the Indonesian slogan as contained in the Garuda bird symbol. So, everything that has the potential to disrupt the NKRI, including provocation, blasphemy, moreover the movement which states that nationalism which is not compatible with Islamic teachings must be given a counter discourse.

Based on the description that has been stated in Himasal's work, there are at least some important things related to nationalism or nationalism. The first, it is certainly related to the notion of nationalism itself, also the notion of Himasal nationalism, nationalism in the Indonesian context, including its relation to the urgency of unity and a harmonious life, and finally regarding Himasal's recommendations. The brief description is as follows.

In Himasal's work nationalism is understood as an understanding of nationality and love of the motherland. The concise definition is taken from Kamus Besar Bahasa Indonesia (KBBI) which reads in full "Nationalism is the awareness of membership in a nation that potentially or actually together achieves, maintains and perpetuates the identity, integrity, prosperity and strength of a nation, or is also valid with the spirit of nationality. ${ }^{15}$ Actually, if viewed from the perspective of scientific reasoning, understanding of certain definitions should not be taken from the dictionary. But rather from the formulation made by experts in the field of nationalism, for example Ben Anderson, Anthony Smith, Guibernau, and others. ${ }^{16}$

${ }^{15}$ Tim Bahtsul Masail HIMASAL, Fikih Kebangsaan, 14.

${ }^{16}$ Montserrat Guibernau, Nations without States: Political Communities in a Global Age (Cambridge, Oxford, Malden: Polity Press and Blackwell Publisher, 1999), 13-14. Anderson Benedict, Imagined Communities: Komunitas-Komunitas Terbayang (Yogyakarta: 
Also included is not making a review of many discussions about Islam and nationalism as reference material. Just mention the discussion of M. Natsir, Soekarno, Agus Salim, HAMKA, K.H. Syaifuddin Zuhri, K.H. Zainul Arifin, K.H. A. Wahab Chasbullah, K.H. Masjkur, K.H. Abdurrahman Wahid, Nurcholis Majid, Syafi'i Ma'arif, or reviews on the development of nationalism in the Arab world by Rashid Khalidi and friends, or also the thoughts of Rifa'a Al Tahtawi, 'Ali' Abd Raziq, and Farag Fouda. ${ }^{17}$ This happened perhaps indeed the study references on Islam and nationalism were not included in the reading list of the 'bahtsul' participants who were indeed from the traditional Lirboyo boarding school. Another possibility is that the babtsul masail participants felt quite with the opinions of the Kyai (especially those who were still one of the Lirboyo boarding school alumni families, such as K.H. Maimun Zubair) and the previous ulama related to nationalism.

Another thing that might be a consideration is also because the aim of the publication of the future babil results was intended to show the world's contribution to Islamic life in Indonesia frame, so that references were also selected which were familiar and became references for the ulama and santri during this. Referring to opinions or other descriptions that are unfamiliar in the world of traditional pesantren (salafiyyatun). Therefore, it would be easier if the reference was indeed familiar used in the pesantren world for a long time, not a "foreign" reference and would potentially confuse the reader (read: the santri) who were familiar with the boarding school's typical references.

INSIST dan Pustaka Pelajar, 2008), 8-11. in Philip Spencer and Howard Wollman, Nationalism: A Critical Introduction (London, Thousand Oaks, New Delhi: SAGE Publications, 2002), 2-3.

${ }^{17}$ Abdurrahman Wahid, Ilusi Negara Islam: Ekspansi Gerakan Islam Transnasional Di Indonesia (Jakarta: The Wahid Institute, 2009). Erwin Kusuma and Khairul, Pancasila Dan Islam: Perdebatan Antar Parpol Dalam Penyusunan Dasar Negara Di Dewan Konstituante (Jakarta: Pusat Studi Pancasila UGM, 2008). Luthfi Assyaukanie, Ideologi Islam Dan Utopia: Tiga Model Negara Demokrasi Di Indonesia, Trans. Samsudin Berlian (Freedom Institute, 2011), Rashid Khalidi, The Origins of Arab Nationalism (New York: Columbia University Press, 1991). 
Nevertheless, the nationalism which is understood as an understanding of nationality or the love of country can adequately represent the spirit and practice of nationalism carried out by Santri and Nahdliyin citizens in general. The nationalism as the love of the motherland in this book by Himasal is corroborated by the arguments of the hadith narrated by Imam Bukhari:

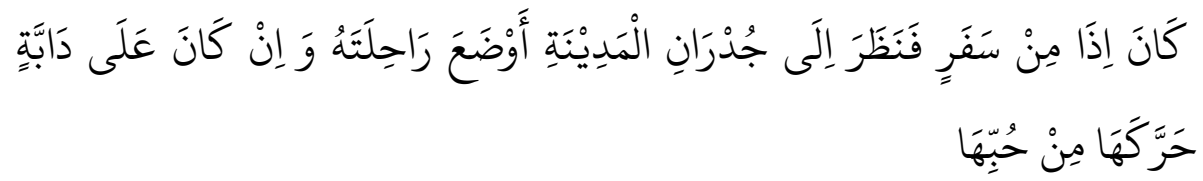

When the Prophet Mubammad returned from traveling and saw the wall of the city of Medina, he accelerated the pace of his camels, and when riding a mount (like a horse), he moved because of his love for Medina (HR. Bukhori).

The Himasal bahtsul masail team relies on the explanation or meaning of the hadith above in the description of Al-Hafiz Ibn Hajar AlqAsqalani that "In that hadith there are indications of the virtue of Medina and it is suggested that he loves the homeland and longs for him". ${ }^{18}$

In addition, the notion of nationalism as a love for the homeland also refers to the explanation of Ismail Haqqi in the interpretation of Ruh al-Bayan regarding the interpretation of Q.S. al-Qasas, 28: 85:

Indeed, [O Mubammad], He who imposed upon you the Qur'an will take you back to a place of return. Say, "My Lord is most knowing of who brings guidance and who is in clear error." (Q.S. al-Qasas, 28: 85).

This verse is translated as a sign that the love of the homeland is part of faith. The revelation of his verse is a compilation on the journey to migrate to Madinah. The Messenger of Allah was very longing for Mecca, the verse came down which means "Allah who asks you (the laws) of the Koran, will really be moved to the place of return. ${ }^{19}$

The Himasal team also referred to the narration of Umar bin Khattab which stated "If there was no love for the homeland, surely a country that would be destroyed, so by loving the homeland, the countries would be

${ }^{18}$ Tim Bahtsul Masail HIMASAL, Fikih Kebangsaan, 15.

${ }^{19}$ Tim Bahtsul Masail HIMASAL, Fikih Kebangsaan, 16. 
prosperous". Then, the Bahtsul Masail team also relied on Syaikh Ismail bin Muhammad Al-Aljuni's opinion that "Love of the homeland is a positive thing if the reason is to connect brotherhood and love the poor or orphans". ${ }^{20}$ The nationalism is the same as the love of the homeland in the work of Himasal is also confirmed by K.H. Maimun Zubair in his introduction to this book which states that the Prophet Muhammad was a person who loved Arabia as his country. If the Prophet Muhammad himself upheld the Arabs because he was Arab, then we must also uphold the Indonesian people because we are part of the Indonesian nation as an expression of the love of the homeland in part from faith. ${ }^{21}$ The pattern of the -istinbat- legal method used by Himasal in formulating nationalism interpretations is dominated by the qauliyab method in which the settlement of religious problems refers directly to the texts of the Imam of the school which are mostly Syafi'iah. ${ }^{22}$ These arguments are clearly a proposition for the legitimacy of the Indonesian state seen from the perspective of Islam. Perhaps when nationalism is understood as love of the homeland, it is analogous to how we also have to love ourselves, our families, our neighbors, our possessions, because it is human nature.

In hermeneutic terms, it seems that it can be interpreted that the Bahtsul team of 'Himasal' did not interpret the love of the land as a nationalism or nationalism that placed the highest love of a human being on the homeland - as understood by HTI. ${ }^{23}$ Someone who loves his homeland - like the Prophet Muhammad SAW loves Mecca - cannot be convicted of not love for Islam, because the homeland is categorized as a place of birth, life and civilization, on the other hand Islam is a religion or vision of life. Judging from the nomenclature of both of them is not the same. Conclusions that are not if A then B only applies if conclusion A automatically disagrees with $\mathrm{B}$, and both $\mathrm{A}$ and $\mathrm{B}$ are the same category,

${ }^{20}$ Tim Bahtsul Masail HIMASAL, Fikih Kebangsaan, 15-17.

${ }^{21}$ Tim Bahtsul Masail HIMASAL, Fikih Kebangsaan, v.

22 Ahmad Zahro, Tradisi Intelektual NU: Lajnab Babtsul Masail, 1926-1999 (Yogyakarta: LKiS, 2004), 167.

${ }^{23}$ Ngisomudin, "Gerakan Politik HTI Berbalut Dakwah Menuju Khilafah Islamiyyah." 
for example both religion, ideology, science. In this case if you agree with the teachings of Islam, automatically disagree with Christian teachings. This happens because the teachings of A (for example Islam) are contained in it claims other truths that deny, namely B, C, D, and others (eg Christian, Buddhist, Confucian). If not Islam, the logical consequences can be Christian, Hindu, Buddhist, Confucian, and others. Not if not Islam must be capitalist, socialist, nationalist, and the like. The categorization is different.

The arguments presented by Bahtsul Masail team (2018) show that the proposition of being Islamic does not mean that it is unlawful to love the country. The definition of love for the motherland seems to be localized or limited to one's position as a citizen. In addition, it is also understood that the love of the motherland is not love that is absolute beyond love for religion, the Prophet, and Allah. Love the homeland when understood as part of faith can also be interpreted that by loving the homeland means to love all people, citizens, and the environment that exists in the homeland (read: Indonesia).

The love of the homeland is also an effort to establish harmony in a country context which eventually also becomes one of the reasons why the Muslims are safe to carry out Islamic teachings especially with the conditions of the Indonesian people who are very religious, having ethnic and cultural diversity. When imposing a form of state that is formally based on Islam, it is feared that it will trigger tensions and conflicts, especially from non-Islamic circles as in the long history of the establishment of the Indonesian state. Thus preventing or rejecting harm must take precedence over taking advantage, as in the rules of the usul alfiqh:

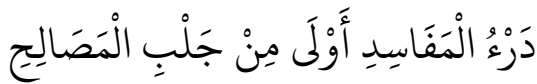

Eliminating misfortune must take precedence over taking advantage.

If it is drawn on the characteristics of NU in the historical context of the development of Islam in the archipelago and the relationship of Muslims - especially NU - with the state, the understanding that nationalism is the love of the homeland does not conflict with the teachings 
of Islam. NU scholars who are solid in their scientific basis, are connected with scientific links with Ulama in the Middle East, and even many who become jurists, Sufism and language seem to make an effort to understand things by weighing their categories clearly. Becoming a jurist must certainly understand the categories of many things, such as legal sources, reasoning methods, and legal products. Sufism experts must also understand differences of heart, lust, and reason. Linguists must also understand many categories of words, sentences, and terms in grammar. ${ }^{24}$ For the santri and Nahdliyin citizens, the love of the homeland is an ethic that has been taught since childhood and has never been understood as worship the nation.

Historically reasoning that nationalism does not conflict with Islam have also been exemplified by the NU when there was a polemic about Pancasila as a state principle. It was stated that Pancasila is not a religion, so it does not need to be opposed to Islam..$^{25}$ Of course the characteristic of the Sunni political attitude which is the basis of NU's view which tends to take a middle ground and is not confrontational with the state authorities also has a role in paving the way for NU's reasoning and attitude in accepting the Pancasila as the basis of the Indonesian state. This characteristic also seems to have been passed down from generation to generation by the propagators of Islam in the archipelago since the time of Walisongo who were able to creatively separate the cultural products and religious beliefs of the local people, until finally the birth of the archipelago's Islamic cultural tradition that was unique, but not against Islamic teachings. Sufistic elements may also have contributed to build understanding of love.

\section{The consequences of being Muslim in Indonesia}

${ }^{24}$ Nurcholish Majid, Bilik-Bilik Pesantren: Sebuah Potret Perjalanan (Jakarta: Dian Rakyat, 2010). Zamakhsyari Dhofier, Tradisi Pesantren: Studi Pandangan Hidup Kyai Dan Visinya Mengenai Masa Depan Indonesia (LP3ES, 2011). Zamakhsyari Dhofier, Tradisi Pesantren: Studi Pandangan Hidup Kyai dan Visinya Mengenai Masa Depan Indonesia, (Jakarta: LP3ES, 2011).

${ }^{25}$ Feillard, NU Vis a Vis Negara; Pencarian Isi, Bentuk Dan Makna, 211-36. 
The chapter IV by Himasal (2018) explains clearly the arguments regarding the urgency of tolerance between Muslims and non-Muslims, especially in the Indonesian context. Some things exemplified include wishing merry Christmas, guarding the church, entering other religious places, giving and receiving donations to non-Muslims, visiting and receiving non-Muslim guests, and the importance of preaching by putting grace. It was even stated that celebrating other people's religious days is permissible if in a state of urgency. Supporting the urgency of tolerance in order to build harmony of the people. Chapter V presented the arguments that provocations, allegations of hypocrisy, infidelity, wickedness, berating increasingly, and spreading false news could potentially cause disunity. The references include the opinion of Al-Syirbini, Ibn Al-Jauzi, Said Ramadhan Al-Buthi, Habib Zaid bin Ibrahim bin Yahya Al-Zamani, K.H. Sahal Mahfuzh, Izzuddin Ibn Abdissalam and others.

Basically these themes can be included in the discussion of the urgency of unity and harmony in the life of the nation and state. The definition of unity is not even understood as a union between Muslims only, but also the unity of fellow children of the nation, until in Chapter II this book was given a very interesting title, namely "NKRI Harga Mati". The subtitles contain the urgency of unity and the danger of disunity why must defend the Unitary of Indonesia, and that Pancasila does not conflict with Islamic teachings. In this case, it is clear that what actually opposed is the argument of Hizbut-Tahrir and the like that if it is Muslim, the form of the country must be al-Khilafah al-Islamiyyah in the style of Hizbut-Tahrir. The team explained that the shape of the state in Islamic teachings was part of al-siyasah. ${ }^{26}$

Maintaining the Unitary of Indonesia is also understood as the most effective al-siyasah al-syariyyah, or ijtihad to accommodate the benefit of religious life in the archipelago with all its diversity. The team in this case refers to the opinions of Ibn Al-Qoyyim Al-Jauziyah and Imam Ghazali. ${ }^{27}$ What was formulated by the team also confirmed what had been decided

${ }^{26}$ Tim Bahtsul Masail HIMASAL, Fikih Kebangsaan, 17-19.

${ }^{27}$ Tim Bahtsul Masail HIMASAL, 20-21. 
by the NU in previous periods. Starting from the resolution of jihad issued by Hadratus Syaikh Hasyim y Ash'ary in 1945 to the National Consultation (Munas) of the NU in 1983 in Situbondo. It was decided that Pancasila as the basis and philosophy of of Indonesia was a fundamental principle, but not religion, could not replace religion, and was not used to replace the religious position. ${ }^{28}$

The decision of the team also - hermeneutically - can be understood that the consequences of the love of homeland in Indonesia context must be directed at the attitude of rejecting understanding of movements that contradict the 4 pillars of the nation, namely NKRI, Bhinneka Tunggal Ika, Pancasila and The 1945 Constitution and must also reject all potential efforts to undermine national unity, then must respect, obey, and guard the government of the Indonesia constitutionally by al-amr bi al-ma'rufi wa alnabi' al-munkar and the laws, and invites all elements to always maintain national unity and harmony in religious life, nation and state to achieve a peaceful country, baldatun thayyibatun wa rabbun ghafur. ${ }^{29}$ Thus, understanding that nationalism is the same as the love of the motherland is a long-standing socio-historical heritage in the world of the pesantren which arguments are strong.

In the last section of this discussion, it is interesting to examine why in the book by Himasal (2018) it does not explicitly point out that the object that was targeted by the argumentation was hardline Islamic movements such as the FPI and the transnational movement, Hizbut-Tahrir? Hermeneutically, by looking at the historical traces and cultural characteristics of the santri, the Kiai always warned not to do things that could cause conflict. Only for matters of a basic nature, aqidah, for example, the new Kyai directly point to the name to make it easier for the people to understand. For example K.H. Hasyim Asy'ari immediately appointed the Wababi movement and several other figures that had to be shunned related to the faith in his Ablussunnah Wal Jama'ab treatise. ${ }^{30}$

\footnotetext{
${ }^{28}$ Tim Bahtsul Masail HIMASAL, 30.

${ }^{29}$ Tim Bahtsul Masail HIMASAL, 91-92.

${ }^{30}$ Hasyim Hadratussyaikh Asy'arie, Risalah Ablusunnah Wal Jama'ah, Edisi Tejemah (Yogyakarta: LKPSM, 1999), 8.
} 
The characteristics of K.H. Maimun Zubair as an adviser appeared moderate, humble, never blasphemed, cursed, and provoked Muslims for certain purposes. As it is known by the general public, the characteristics of FPI are relatively harsh, many cases show the character of the violence in the community. An example is the case of Munarman (FPI official) who watered the face of the University of Indonesia (UI) sociologist Tamrin Tomagola in a live broadcast on TVONE.

\section{Domination of Qauliyah Reasoning}

As a result of documentation from bahtsul masail, it can be seen that this figh reasoning method by Himasal (2018) relatively reflects the characteristics of how the santri formulate a particular law. Based on the identification of trends or types of legal reasoning methods used, it can be seen that Himasal's work tends to use Qauliyyah's reasoning, which is to take the finished legal product from authoritative sources, namely the text of the books of the priest's school or the books compiled by his followers. The Qauliyah method is the first method taken when resolving a religious problem. If this method does not find a reference to the problem under study, the next step is to take the ilhaqiy method then the Manhajiyya method. $^{31}$

The dominance of the Qauliyah method used by Himasal can be seen for example in discussing that Pancasila does not conflict with Islamic values. Himasal Bahtsul Masail Team refers to the opinion of Ulama, among others Abdullah bin Bayyah in Sina 'at al-Fatwa wa Fiqh al-Aqaliyyat, Ibn Hisham in al-Sirah al-Nabawiyyah, Ibn al-Qayyim al-Jauzi in Zad alMa'ad fii Huda Khair al-'Ibad, Habib Zaid bin Ibrahim bin Yahya al-Yamani in a paper on the conference of world Ulama in Pekalongan. ${ }^{32}$

Another example, related to the urgency of respecting the government, the prohibition of rebelling against the legitimate government, the ethics of al-amr al-ma'rufi wa al-nahi an al-munkark to the government, are based on the opinions of some ulama such as

${ }^{31}$ Zahro, Tradisi Intelektual NU, 167-69.

${ }^{32}$ Tim Bahtsul Masail HIMASAL, Fikih Kebangsaan, 27-30. 
Abdurrauf al-Munawi in al-Taysir bi Syarh al-Jami'i al-Saghir, Abdul Wahab al-Sya'roni in al-Minan al-Kubra, Yahya bin Syaraf al-Nawawi in Al-Minhaj Syarb Sabih Muslim bin al-Hajaj, Muhammad bin Ahmad al-Ramli in Gayat al-Bayan, Zakaria bin Muhammad bin Zakaria al-Ansari in Gurar alBahiyyah, Wahbah al-Zuhaili in al-Figh al-Islam wa Adillatuh, and Abu alFadhl al-Senori in Syarh al-Kawakib al-Lama'ah. ${ }^{33}$ Some of these references are discussed in the body of the writing.

Regarding tolerance of Muslims and non-Muslims also refers to Shaykh Ramadhan al-Buthi in al-jibad fii al-Islam, Bakbith al-Muthi 'in alMajmu' Syarh al-Mubazzab, Al-Qadhi 'Iyadh and Ahmad bin Muhammad alShamani in al-Sifa bi Ta'riif Huquq al-Mustafa, Ismail bin Umar bin Kasir in Tafsir Ibn Kasir, al-Syatibi in al-Muwafaqat, al-Munawi in Faidh al-Qodir, Ibn Qayyim al-Jawriyyah in Abkam Abl al-zimmah, and Syaikh Ramadhan Al-Buthi in al-Guluw wa al-Tatarruf. ${ }^{34}$ If you register again, there are certainly many others. Thus, it is clear that in formulating an opinion of the Team indeed tends to use the Qauliyyah approach. This tendency seems to be influenced by the culture that was built in the pesantren in the Nahdlatul Ulama (NU), which is not in a hurry to do the Manhajizyah ijtihad if it can be traced to the opinions of the previous Ulama.

Ahmad Zahro explained that on January 26-28 1990 Halaqah was held in the Islamic Boarding School Manba'ul Ma'arif, Denanyar, Jombang. On this occasion a decision was made that the bahtsul masail method contained two schools, namely the Manhajiyyah and Qauliyyah. KH. Muhammad Ahmad Sahal Mahfudh and friends at a seminar at Watucongol Islamic Boarding School Magelang, formulated that in understanding the text of the book — including certain fiqh legal formulations - it must be accompanied by reading its historical social context, developing the ability of observation and analysis of the text. multiply al-muqabalah (comparison of different things) with other books, and expose classical books to actual discourse and communicative

${ }^{33}$ Tim Bahtsul Masail HIMASAL, Fikih Kebangsaan, 37-41.

${ }^{34}$ Tim Bahtsul Masail HIMASAL, Fikih Kebangsaan, 49-54. 
Iis Kholilah

language. ${ }^{35}$

Qauliyyab's dominant reasoning in this book is not without risk for the efforts of Islamic scientific development, especially in jurisprudence. In this case, as can be seen in the description of the social, cultural and historical contexts of various ancient religious decisions in this book, it does not present a description of the case and its social, cultural and historical context. It is less able to place real socio-historical factors in Indonesia as a consideration in legal formulation, because it focuses on exploring the opinions of previous Ulama. It could be if it is juxtaposed with Manhajiyyah reasoning, a more substantial legal formula will be obtained. The cases which were later responded to by the early publications of Himasal were a truly Indonesian contextual case in the post-reformation period of 1998. Therefore, the reasoning of Qauliyab would have been stronger if juxtaposed with the Manhajiyya reasoning in legal reasoning as suggested by KH . Muhammad Ahmad Sahal Mahfudh.

\section{Consequences for Readers}

In the book by Himasal, the narrative model shifts from general topics, special topics, and then to the general statement of opinion which is written directly based on the opinions of several scholars which are then written in the body of writing and footnotes. In the opening remarks in the book, K.H. Abdulloh Kafabihi Mahrus, as Chair of Himasal, stated that this book was very important especially for the Santri. In his description, santri should not only be qualified in reading classical books, but also deepen themselves with national knowledge. He said, students who only assess problems from the halal-haram view point, without considering the perspective of the welfare of the nation and state tend to act conservatively.

Departing from the narrative model and analysis carried out by Bahtsul Masail Himasal team, several things appeared which might be called the shortcomings of this work. First, because this work is assumed to be for santri readers, the general reader will find it difficult to understand

${ }^{35}$ Zahro, Tradisi Intelektual NU, 128-31. 
Arabic-language texts that are used as references by the Ulama, while in Indonesian texts in the body of writing also do not fully explain in detail and detail. This 100 page thick book does look concise. Second, the reviews of nationalism or nationalism and others in this book are not compared to the views of the pro-Khilafah Islamiyah parties from Hizbut-Tahrir and friends, so that there is still a question space whether the arguments presented in this book have answered the arguments that were also presented by Hizbut-Tahrir and friends?

In fact, as the writer explained in the previous discussion, in the work, it is not clearly stated or not explicitly written who the parties that commit violence, blasphemy, invective, provocation, and reject nationalism and Pancasila as the basis of the state. This certainly may be very risky. In this case the reader does not understand who exactly is meant as a provocateurs and those who do not love the country or disagree with the Pancasila as the basis of the country. Perhaps Himasal considers that the parties and actors of the things criticized in this work are already clear, so there is no need to explain them. Perhaps also because this work is relatively written for the segmentation of the santri, so the effort to understand this work will be part of a discussion that is more limited in the santri's own environment, so that the potential to cause conflict with other parties (read: FPI, Hizbut-Tahrir and sympathizers) can be minimized.

\section{Conclusion}

Based on the previous discussion, 2 (two) main conclusions can be drawn, namely (1) the context of the occurance of the text "Fikih Kebangsaan: Merajut Kebersamaan di Tengah Kebhinnekaan " (2018) is the condition of Muslims in Indonesia who begins to be influenced by a potentially divisive understanding the people and the Indonesian people, namely the presence of the al-Khilafah al-Islamiyy a brought by Hisut-Tabrir, besides that it is also based on the awareness of the harsh or extreme understanding of religion and understanding of terror which manifests itself in ISIS (2) the conception of nationalism by Bahtsul Masail Himasal team is understood as a nationalism, namely the love of the motherland, 
which does not conflict with Islamic values and teachings, being nationalist does not automatically become non-Muslim, being Muslim does not mean that nationalism and religion are two things that are in different categories and do not exclude each other, (3) the legal reasoning model used by the Himasal Bahtsul Masail team tends to Qauliyyah. It could be that when juxtaposed with Manhajizya reasoning, a more substantial legal formula will be obtained, and (4) the discussion of the theorems put forward has not been juxtaposed with theorems and arguments from parties who do not agree with nationalism in Islam so that they can potentially obscure the readers' understanding .

\section{Bibliography}

Assyaukanie, Luthfi. Ideologi Islam Dan Utopia: Tiga Model Negara Demokrasi Di Indonesia, Trans. Samsudin Berlian. Jakarta: Freedom Institute, 2011.

Benedict, Anderson. Imagined Communities: Komunitas-Komunitas Terbayang. Yogyakarta: INSIST dan Pustaka Pelajar, 2008.

Dhofier, Zamakhsyari. Tradisi Pesantren: Studi Pandangan Hidup Kyai Dan Visinya Mengenai Masa Depan Indonesia. Jakarta: LP3ES, 2011.

Feillard, Andree. NU Vis a Vis Negara; Pencarian Isi, Bentuk Dan Makna. Yogyakarta: LKiS, 2008.

Gabrillin, Abba. "Perjalanan Kasus Rizieq, Penodaan Pancasila hingga 'Chat WhatsApp' yang Berujung Dihentikan Halaman all." KOMPAS.com. Accessed October 2, 2018. https://nasional.kompas.com/read/2018/06/17/09394031/perj alanan-kasus-rizieq-penodaan-pancasila-hingga-chat-whatsappyang.

Given, Lisa. The SAGE Encyclopedia of Qualitative Research Methods. 2455 Teller Road, Thousand Oaks California 91320 United States: SAGE Publications, Inc., 2008. https://doi.org/10.4135/9781412963909.

Guibernau, Montserrat. Nations without States: Political Communities in a Global Age. Cambridge, Oxford, Malden: Polity Press and Blackwell Publisher, 1999.

Hadratussyaikh Asy'arie, Hasyim. Risalah Ablusunnah Wal Jama'ah, Edisi Tejemah. Yogyakarta: LKPSM, 1999. 
Hardiman, F. Budi. "Kritik Ideologi, Menyingkap Pertautan Pengetahuan Dan Kepentingan Bersama Jurgen Habermas." Yogyakarta: Penerbit Kanis-Ius, 2009.

Howard, Roy J. "Pengantar Teori-Teori Pemahaman Kontemporer: Hermeneutika: Wacana Analitik, Psikososial Dan Ontologis, Terj." Kusmana Dan MS. Nasrullah,(Bandung: Nuansa, Cet. II 2001), 2001.

Kerjasama, Biro Humas, Hukum dan. "Kewenangan Legal Administratif Kemenkumham Sebagai Tindak Lanjut Perppu Nomor 2 Tahun 2017." Kementerian Hukum dan Hak Asasi Manusia Republik Indonesia. Accessed July 30, 2019. https://kemenkumham.go.id/publikasi/siaran-

pers/kewenangan-legal-administratif-kemenkumham-sebagaitindak-lanjut-perppu-nomor-2-tahun-2017.

Khalidi, Rashid. The Origins of Arab Nationalism. New York: Columbia University Press, 1991.

Kurdi, Muqarramah Sulaiman. "Madrasah Ibtidaiyah dalam Pandangan Dunia: Isu-Isu Kontemporer dan Tren dalam Pendidikan." Al Ibtida: Jurnal Pendidikan Guru MI 5, no. 2 (October 31, 2018): 23148. https://doi.org/10.24235/al.ibtida.snj.v5i2.3194.

Kusuma, Erwin, and Khairul. Pancasila Dan Islam: Perdebatan Antar Parpol Dalam Penyusunan Dasar Negara Di Dewan Konstituante. Jakarta: Pusat Studi Pancasila UGM, 2008.

Lutfi, Mohamad Alwi, Karim Suryadi, and Endang Somantri. "Role Of Nahdlatul Ulama in Fostering Indonesian Nationalism in Effort to Realize Baldatun Thayyibatun Wa Robbun Ghofur." JURNAL CIVICUS 18, no. 2 (December 2, 2014). http://ejournal.upi.edu/index.php/civicus/article/view/2042.

Majid, Nurcholish. Bilik-Bilik Pesantren: Sebuah Potret Perjalanan. Jakarta: Dian Rakyat, 2010.

Malpas, Jeff, and Hans-Helmuth Gander. The Routledge Companion to Hermeneutics, 2015.

Murod, Abdul Choliq. "Nasionalisme dalam Pespektif Islam " Citra Lekha 15, no. 2 (September 2, 2011): 45-58.

Ngisomudin, KH. Ahmad. "Gerakan Politik HTI Berbalut Dakwah Menuju Khilafah Islamiyyah,” n.d., 14.

Palmer, Richard E. Hermeneutika: Teori Baru Mengenai Interpretasi. Pustaka Pelajar, 2003. 
Iis Kholilah

Rasyid, Makmun. Hiz̧but Tabrir Indonesia: gagal paham khilafah. Tangerang: Pustaka Compass, 2016.

Setiawan, Zudi. Nasionalisme NU. Semarang: Aneka Ilmu, 2007.

Spencer, Philip, and Howard Wollman. Nationalism: A Critical Introduction. London, Thousand Oaks, New Delhi: SAGE Publications, 2002.

Thompson, Jhon. "Kritik Ideologi Global: Teori Sosial Kritis Tentang Relasi Ideologi Dan Komunikasi Massa, Terj." Haqqul Yakin. Yogyakarta: IRCiSoD, 2006.

Thompson, John B. Critical Hermenentics: A Study in the Thought of Paul Ricoeur and Jürgen Habermas - Kindle Edition by John B. Thompson. Cambridge, New York, Melbourne: Cambridge University Press, 2003.

Tim Bahtsul Masail HIMASAL. Fikih Kebangsaan: Merajut Kebersamaan di Tengah Kebbinnekaan. Lirboyo: Lirboyo Press dan LTN HIMASAL, 2018. https://lirboyo.net/ fikih-kebangsaan-merajutkebersamaan-di-tengah-kebhinnekaan/.

Wahid, Abdurrahman. Ilusi Negara Islam: Ekspansi Gerakan Islam Transnasional Di Indonesia. Jakarta: The Wahid Institute, 2009.

Zahro, Ahmad. Tradisi Intelektual NU: Lajnah Babtsul Masail, 1926-1999. Yogyakarta: LKiS, 2004. 